\section{Capital errors}

\section{Actual Innocence: Five Days to Execution, and Other Dispatches From the Wrongly Convicted By Barry Sheck, Peter Neufeld \& Jim Dwyer}

Doubleday \$24.95 (US). ISBN 0-385-49341-X, 2000

Reviewed by Philip R. Reilly

Shriver Center, Waltham, Massachusetts 02250, USA

On 30 January, 2000, Illinois Governor George Ryan made the unprecedented decision to block all executions in his state, pending a formal investigation of why Illinois has had more death sentences overturned than carried out. Since 1977 (the year Illinois reinstated the death penalty), 13 men who had been sentenced to die were instead released from prison because they were shown to be innocent or wrongfully convicted. In one case, the prisoner, Anthony Porter, had once been just two days from execution. Given the gravity of the death sentence, how could there possibly be so many errors in trials for capital crimes? If you want the answer, read Actual Innocence, a fast-paced, searing indictment of the criminal justice system by the United States' most famous 'DNA' defense

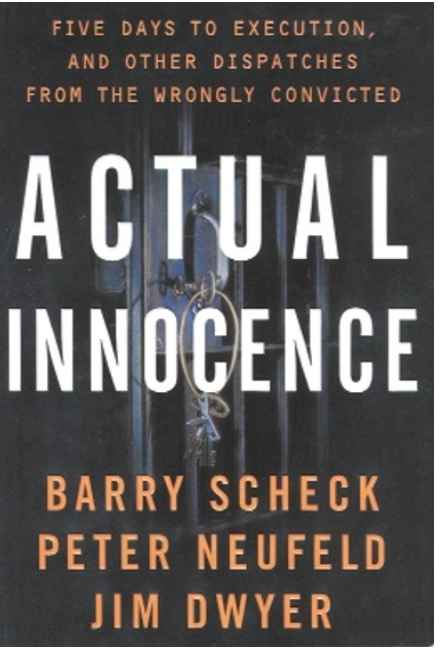

there are heroes, too: harried public defenders; family members who never give up believing that their relative was wrongfully convicted; prosecutors who cooperate to overturn the convictions that they fought so hard to obtain; and Barry Sheck, Peter Neufeld and the other lawyers and many law students who have served The Innocence Project, a public law clinic at Benjamin Cardozo Law School in New York that specializes in using DNA evidence to obtain the freedom of innocent men and women.

The authors build each chapter around a single case, using it to illustrate some fundamental flaw in the justice system. A consistent theme across the chapters is the weakness of the evidence upon which a man may sometimes be found guilty of a heinous crime. One rape conviction was obtained by faulty eyewitness testiand Peter Neufeld, and Jim Dwyer, a prominent crime journalist who writes for the New York Daily News.

Actual Innocence is a tale with many villains: venal detectives who manufacture false confessions; unscrupulous prosecutors who suppress evidence; jailhouse snitches who falsely claim to have heard confessions so they can get their own sentences reduced; charlatan scientists who repeatedly lie at trials; and alleged forensic experts who have built a pseudo-science called "comparative light microscopic analysis of human hair". Other problems that Sheck and Neufeld expose are even more troubling: the astounding error rate of eyewitness evidence; the misuse of the line-up system; and, most disturbingly, the racial bias that seems built into the very timbers of the house of justice. But often critically dependent on the good will of a reluctant prosecutor.

Fourteen men in Illinois and seven in New York have already been released from jail after being exonerated by DNA evidence, most after already having spent years in prison. In all, the book provides data on more than 50 persons who have been released after DNA evidence exonerated them, showing that they served a median of eight years. One wonders how many more individuals are in prison today for major felonies that they did not commit. Is it one per cent of the total? Two per cent? Five per cent? Based on experiences through 1999, it seems certain that there are hundreds of such persons. The Innocence Project will be busy for a long time.

Some of the most interesting material in Actual Innocence is in Appendix 1, in which the authors suggest reforms of the criminal justice system to protect the innocent. Most crucial among them is to ensure that a prisoner is able to obtain DNA-testing if the results would have a reasonable chance of exonerating an innocent party. In late 1999, a subcommittee of the National Commission on the Future of DNA Evidence (convened two years ago by Attorney General Janet Reno and on which both Barry Sheck and this writer serve) published recommendations on post-conviction DNA testing. This report urged prosecutors to cooperate with requests for DNA testing if the exclusionary results would exonerate the petitioner. Such a policy would serve justice well.

Although there is much in this book about DNA forensics, it is of necessity presented in a general, non-technical way that some scientifically trained readers may find frustrating. And yes, there are a few errors in the presentation. But in the larger scheme, these issues are of no importance to the message that the authors seek to convey. Some, especially scientists, may find Actual Innocence polemical, biased and at times self-promoting. But Sheck and Neufeld work in a world that is vastly different from the laboratory. They do not have the benefit of control groups; their reports must, by necessity, be anecdotal. Still, they have presented evidence to their readers that deserves to be weighed and judged. I have done so, and I conclude that, among the many wonderful benefits that modern molecular biology has provided, one of the greatest is a new tool for justice. 